\title{
PENAMBAHAN ARANG SERBUK GERGAJI PADA BRIKET JERAMI SEBAGAI BAHAN BAKAR ALTERNATIF
}

\author{
Anisa Aulia Marantika ${ }^{1, a)}$, Sulhadi, Teguh Darsono \\ ${ }^{1}$ Program Studi Magister Pendidikan Fisika Pascasarjana UNNES, Jl. Kelud Utara III, Semarang 50237 \\ Email: a)aulia.anisa54@yahoo.co.id
}

\begin{abstract}
Abstrak
Jerami merupakan hasil samping pertanian yang ketersediannya melimpah dan memiliki kandungan unsur karbon yang cukup besar. Salah satu pemanfaatan jerami adalah sebagai briket bahan bakar. Peningkatan kualitas briket dapat dilakukan dengan penambahan serbuk gergaji. Penelitian ini bertujuan untuk mengetahui pengaruh penambahan serbuk gergaji pada kualitas briket jerami, Perbandingan komposisi arang serbuk gergaji terhadap briket jerami padi divariasikan antara 30\%-70\% dengan variasi tekanan antara1000kg-3000kg. Kualitas briket ditunjukkan dengan uji porositas dan uji temperatur. Hasil penelitian didapatkan komposisi pemcampuran yang menghasilkan mutu briket terbaik dengan porositas terkecil sebesar $8,93 \%$ dan temperatur pembakaran terbesar $377{ }^{\circ} \mathrm{C}$ adalah komposisi jerami padi $30 \%$ dan serbuk gergaji $70 \%$ dengan tekanan pengempaan $3000 \mathrm{~kg}$.
\end{abstract}

Kata-kata kunci: serbuk gergaji, briket jerami, porositas, temperatur

\begin{abstract}
Straw is a by-product of agriculture that is abundant in availability and has a considerable carbon element. One of the utilization of straw is as fuel briquettes. Improving the quality of briquettes can be done with the addition of sawdust. This study aims to determine the effect of the addition of sawdust on the quality of straw briquettes. Comparison of sawdust charcoal composition to rice straw briquettes is varied between $30 \%-70 \%$ with pressure variation between $1000 \mathrm{~kg}-3000 \mathrm{~kg}$. Quality of briquettes is shown by porosity test and temperature test. The result showed that mixing composition resulted in the best quality of briquettes with the smallest porosity of $8.93 \%$ and the largest combustion temperature of $377{ }^{\circ} \mathrm{C}$ was $30 \%$ rice straw composition and $70 \%$ sawdust with $3000 \mathrm{~kg}$ forging pressure.
\end{abstract}

Keywords: sawdust, straw, porosity, temperature

\section{PENDAHULUAN}

Tingkat pemakaian bahan bakar terutama bahan bakar fosil di dunia semakin meningkat seiring dengan semakin bertambahnya populasi manusia dan meningkatnya laju industri di berbagai Negara di dunia. Jika hal ini terjadi terus-menerus maka akan menyebabkan terjadinya krisis bahan bakar. Sehingga, perlu dibuat sumber energi alternatif yang terbarukan, melimpah jumlahnya, dan murah harganya sehingga terjangkau oleh masyarakat luas [1]. Sumber energf alternatif berasal dari sumber daya alam yang dapat diperbaharui, salah satunya adalah energi biomassa [2]. 
Potensi biomassa di Indonesia yang bisa digunakan sebagai sumber energi jumlahnya sangat melimpah. Biomasa adalah istilah untuk semua jenis material organik yang dihasilkan dari proses fotosintesis. Pemanfaatan limbah memiliki banyak keuntungan, antara lain peningkatan efisiensi energi secara keseluruhan karena kandungan energi yang terdapat pada limbah cukup besar dan akan terbuang jika tidak dimanfaatkan. Manfaat lain adalah penghematan biaya, karena sering kali membuang limbah bisa lebih mahal dari pada memanfaatkannya [3].

Salah satu jenis dari biomasa yang ketersediaannya melimpah adalah jerami padi. Pemilihan material jerami padi pada penelitian ini didasari karena di Indonesia sendiri merupakan negara agraris yang mayoritas hasil pertaniannya berupa padi Menurut data BPS tahun 2013, luas sawah di Indonesia adalah 13,7 juta ha dengan kapasitas produksi padi sekitar 70,87juta ton sehingga potensi jerami padi yang dimiliki Indonesia adalah sekitar 99,22 juta ton [4]. Jerami padi yang merupakan batang dari padi itu sendiri banyak yang tidak dimanfaatkan sehingga menjadi sampah, ataupun jika dimanfaatkan hanya sebatas dibakar langsung di lahan pertanian atau dijadikan sebagai makanan ternak. Pemanfaatan jerami padi sebagai makanan ternak hanya dilakukan sebagian kecil dan sebagian besar jerami padi langsung dibakar di lahan pertanian [5].

Salah satu pengolahan limbah jerami padi adalah menjadikannya sebagai bahan bakar alternatif yaitu briket. Briket arang adalah arang yang diolah lebih lanjut menjadi bentuk briket (penampilan dan kemasan lebih menarik) yang dapat digunakan untuk keperluan energi sehari-hari [6]. Kelebihan dari pengolahan limbah jerami padi menjadi briket adalah tersedianya bahan baku yang cukup banyak dan murah di daerah pertanian di Indonesia. Namun, briket jerami padi mempunyai nilai kalor yang rendah pada waktu pembakaran, maka untuk meningkatkan kalornya perlu adanya campuran bahan lain [7].

Selain hasil samping pertanian, limbah industri penggergajian juga bisa dimanfaatkan untuk sumber energi alternatif. Serbuk gergajian adalah serbuk kayu dari jenis kayu yang sembarang yang diperoleh dari limbah ataupun sisa yang terbuang dari jenis kayu dan diperoleh di tempat pengolahan kayu ataupun industri kayu. Limbah yang dimaksud disini adalah hasil samping yang terbentuk dari kegiatan biomassa kayu atau berserat lingo-sellulosa, suatu bahan baku yang belum termanfaatkan. Adanya limbah yang dimaksud adalah menimbulkan masalah penanganannya yang selama ini dibiarkan membusuk, ditumpuk dan dibakar yang kesemuanya berdampak negatif bagi lingkungan sehingga penanggulangannya perlu dipikirkan.

Salah satu jalan yang dapat ditempuh adalah memanfaatkannya menjadi produk yang bernilai tambah dengan teknologi aplikatif dan kerakyatan sehingga hasilnya mudah disosialisaikan kepada masyarakat. Hasil evaluasi menunjukkan beberapa hal berprospek positif sebagai contoh aplikatif dimaksud dapat diterapkan secara memuaskan dalam mengkonversi limbah industry pengolah kayu menjadi arang serbuk, briket arang, arang aktif [8]. Untuk industri besar dan terpadu, limbah serbuk kayu gergajian sudah dimanfaatkan menjadi bentuk briket arang dan arang aktif yang dijual secara komersial. Namun untuk industri penggergajian kayu skala industi kecil yang jumlahnya mencapai ribuan unit dan tersebar di pedesaan, limbah ini belum dimanfaatkan secara optimal [6]. Sehingga untuk meningkatkan kualitas briket jerami dilakukan dengan penambahan serbuk gergaji.

Pembriketan pada biomasa dapat meningkatkan nilai kalor volumetrik, mengurangi biaya transportasi, pengumpulan/pengepakan, dan penyimpanan (storage). Parameter - parameter yang menentukan dalam pembuatan briket biomasa antara lain adalah tekanan pembriketan, waktu penahanan (holding time), ukuran butir serbuk, jenis bahan pengikat, temperatur pembriketan, dan kandungan air (moisture content) [5]. Selain itu pencampuran formula dengan briket juga mempengaruhi sifat briket [9]. Keunggulan briket bioamasa antara lain biayanya amat murah. Alat yang digunakan untuk pembuatan briket ini cukup sederhana dan bahan bakunya pun murah, bahkan tidak perlu membeli karena berasal dari hasil samping pertanian dan industri penggergajian kayu yang sudah tidak berguba lagi. Bahan baku untuk pembuatan arang ini umumnya telah tersedia disekitar kita.

Pembuatan briket arang dari hasil samping pertanian dapat dilakukan dengan penambahan bahan perekat, dimana bahan baku diarangkan terlebih dahulu, kemudian ditumbuk, dicampur perekat, dicetak dan selanjutnya dikeringkan. Percobaan ini, perekat yang digunakan adalah dari tepung tapioca (kanji). Tepung tapioka merupakan pati yang diekstrak dari singkong. Perekat adalah suatu zat atau bahan yang memiliki kemampuan untuk mengikat dua benda melalui ikatan 
permukaan.Penggunaan bahan perekat dimaksud untuk menarik air dan membentuk tekstur padat atau mengikat dua substrat yang akan direkatkan. Dengan adanya bahan perekat maka susunan partikel akan semakin baik, teratur dan lebih padat sehingga dalam proses pengempaan keteguhan tekanan dan arang briket akan semakin baik. Penggunaan tepung tapioca sebagai perekat karena mempunyai kekuatan perekat yang, mudah didapat dan tidak mengganggu kesehatan. Perekat tapioka umum digunakan sebagai bahan perekat pada briket arang karena harganya relatif murah. Perekat ini dalam penggunaanya menimbulkan asap yang relatif sedikit dibandingkan bahan lainnya [6].

Bahan bakar briket ini dapat dimanfaatkan dengan teknologi yang sederhana, tapi panas (nyala api) yang dihasilkan cukup besar, cukup lama dan aman. Bahan bakar ini cocok digunakan oleh pedagang atau pengusaha yang memerlukan pembakaran yang terus menerus dalam jangka waktu yang cukup lama [8].

Tujuan dari penelitian ini adalah untuk meningkatkan pemanfaatan biomassa dengan membuat briket bioarang sebagai bahan bakar alternatif. Serta untuk mengetahui pengaruh tekanan dari komposisi briket jerami dengan penambahan arang serbuk gergaji terhadap kualitas briket yang dihasilkan.

\section{METODE PENELITIAN}

Alat yang digunakan dalam pembuatan briket jerami padi dengan penambahan serbuk gergaji ini adalah alat press manual yang dilengkapi dengan pencetak briket berbentuk silinder besi dengan diameter $4 \mathrm{~cm}$, ayakan, alat pengaduk, timbangan digital, alat penumbuk, dan alat-alat yang digunakan untuk analisa yaitu gelas ukur, thermometer infrared. Bahan yang digunakan antara lain, jerami padi, serbuk gergaji, tepung kanji (tapioka), dan air.

Pembuatan briket jerami dengan penambahan serbuk gergaji dilakukan dengan cara pertama, bahan baku diarangkan terlebih dahulu, kemudian arang jerami yang telah diayak dicampurkan dengan arang serbuk gergaji dengan perbandingan komposisi arang jerami/ arang serbuk gergaji (J/S): 70/30; 50/50; 30/70 dari massa keseluruhan briket yaitu 20 gram.

Tahap kedua, bahan baku yang telah tercampur rata ditambahkan bahan perekat berupa tepung tapioka sebesar $10 \%$ dari massa briket yaitu sebesar 2 gram. Setelah bahan baku dan perekat tercampur merata, kemudian dimasukkan ke dalam cetakan yang berbentuk silinder.

Tahap ketiga, melakukan pengepresan dengan menggunakan alat press hidrolik manual dengan variasi tekanan $1000 \mathrm{~kg}, 2000 \mathrm{~kg}$, dan $3000 \mathrm{~kg}$ untuk setiap komposisi briket. Tahap keempat, mengeluarkan briket dari cetakan dan mengeringkan di tempat yang tidak terkena sinar matahari secara langsung.

Pengujian mutu briket dilakukan dengan uji porositas dan uji temperature briket. Uji porositas dilakukan dengan prosedur pengujiannya adalah sebagai berikut: menimbang masa awal briket, merendam briket di dalam air selama 1 menit, menimbang masa akhir briket setelah 1 menit, kemudian mencatat perubahan masa briket.

Pengujian temperatur dilakukan dengan cara membakar briket selama 1 menit, kemudian mengukur suhu briket menggunakan termometer infrared.

\section{HASIL DAN PEMBAHASAN}

Bahan baku yang digunakan dalam pembuatan briket bioarang dari komposisi jerami padi dan serbuk gergaji dengan menggunakan bahan perekat tepung kanji (tapioka) yang dicampur air panas dengan variasi tekanan pada saat pengempaan (pengepressan). 


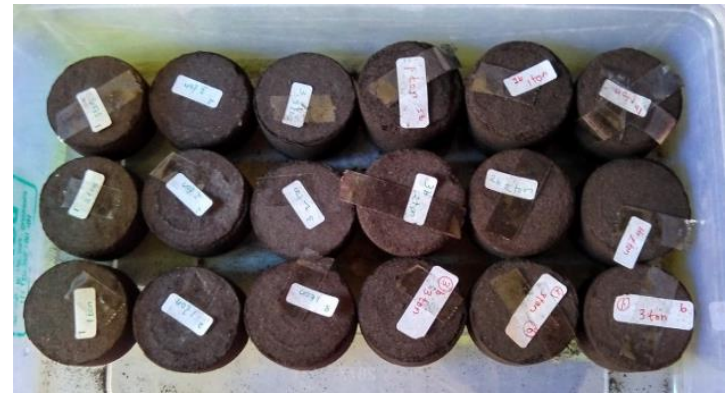

GAMBAR 1. Briket Jerami dengan Penambahan Arang Serbuk Gergaji

Adapun kualitas briket yang dianalisis adalah porositas dan temperaturnya.

TABEL 1. Hasil uji porositas briket

\begin{tabular}{ccc}
\hline $\begin{array}{c}\text { Komposisi (\%) } \\
\text { J : } \mathbf{S}\end{array}$ & Tekanan (kg) & Porositas (\%) \\
\hline \multirow{3}{*}{$\mathbf{7 0}: \mathbf{3 0}$} & 1000 & 16 \\
& 2000 & 11,46 \\
& 3000 & 10,20 \\
$\mathbf{5 0}: \mathbf{5 0}$ & 1000 & 16,76 \\
& 2000 & 12,67 \\
& 3000 & 10,53 \\
$\mathbf{3 0}: \mathbf{7 0}$ & 1000 & 16,32 \\
& 2000 & 12,13 \\
& 3000 & 8,93 \\
\hline
\end{tabular}

Dari hasil penelitian yang didapatkan, diperoleh hasil porositas terkecil adalah 8,93\%. Dengan menggunakan variasi tekanan dapat mengetahui kepadatannya, sehingga semakin tinggi nilai tekanan yang diberikan, semakin meningkatnya density, sehingga dapat kita cari nilai porositasnya dengan menggunakan cara sederhana. Karena semakin kecil nilai porositasnya semakin baik briket dalam penggunaannya [10].

Dari data yang didapatkan, terlihat bahwa, pemberian tekanan berpengaruh pada nilai porositas briket, semakin besar tekanan pengempaan, semakin kecil nilai porositasnya. Pemberian tekanan terbesar $3000 \mathrm{~kg}$, didapatkan hasil porositas terkecil untuk ketiga komposisi. Sedangkan nilai porositas terbesar pada setiap komposisi didapatkan pada tekanan pengempaan $1000 \mathrm{~kg}$. Hal tersebut terjadi karena semakin besar tekanan mengakibatkan partikel terdesak untuk mengisi rongga yang kosong, sehingga berkurangnya porositas pada biobriket [11]. Penambahan tekanan pengepresan menandakan banyaknya butiran-butiran yang menyatu sehingga komposisi briket tersebut semakin rapat, dan ikatan antar serbuk lebih kompak dan kuat.

TABEL 2. Hasil uji temperature briket

\begin{tabular}{ccc}
\hline $\begin{array}{c}\text { Komposisi (\%) } \\
\text { J : S }\end{array}$ & Tekanan (kg) & $\begin{array}{c}\text { Temperatur } \\
\left({ }^{\circ} \mathbf{C}\right)\end{array}$ \\
\hline \multirow{3}{*}{$\mathbf{7 0 : 3 0}$} & 1000 & 205 \\
& 2000 & 261 \\
& 3000 & 283 \\
$\mathbf{5 0 : 5 0}$ & 1000 & 256 \\
& 2000 & 334 \\
& 3000 & 356 \\
$\mathbf{3 0}: \mathbf{7 0}$ & 1000 & 280 \\
& 2000 & 340 \\
\hline
\end{tabular}


Bahan bakar, briket juga harus memenuhi kriteria salah satunya menunjukkan upaya laju pembakaran (waktu, laju pembakaran, dan suhu pembakaran) yang baik [12]. Penambahan serbuk gergaji berpengaruh terhadap temperature pembakaran briket. Hasil uji temperatur diperoleh nilai temperatur pembakaran tertinggi sebesar $377^{\circ} \mathrm{C}$ pada komposisi jerami padi $30 \%$ dan serbuk gergaji $70 \%$ pada tekanan pengempaaan $3000 \mathrm{~kg}$. Sedangkan temperatur terendah pada komposisi jerami 70 $\%$ dan serbuk gergaji $30 \%$ sebesar $205{ }^{\circ} \mathrm{C}$. Hal tersebut sesuai dengan hasil penelitian Subroto (2007) didapatkan bahwa biobriket dengan campuran 30\% jerami : 70\% arang kayu mempunyai temperature pembakaran yang tinggi, sedangkan untuk temperatur pembakaran yang rendah terdapat pada biobriket dengan campuran 50\% arang kayu dan 50\% jerami, hal tersebut disebabkan oleh besar kecilnya nilai kalor yang tedapat pada biobriket-biobriket tersebut.

Serbuk gergaji memiliki nilai kalor yang tinggi, bila dibandingkan jerami padi yang memiliki nilai kalor yang lebih rendah. Nilai kalor briket serbuk gergaji berkisar antara 3943 kal/gram - 4144 $\mathrm{kal} / \mathrm{gram}$. Sedangkan nilai kalor jerami (kal/kg) 3456,483 [12]. Sehingga semakin banyak penambahan serbuk gergaji maka semakin tinggi temperatur pembakarannya. Penambahan tekanan pada setiap komposisi briket juga berpengaruh terhadap temperature pembakarannya. Pada setiap komposisi, semakin besar tekanann, semakin besar temperature pembakarannya, karena pori-pori atau rongga briket kecil, sehingga tinggi temperaturnya.

\section{SIMPULAN}

Serbuk gergaji kayu dan jerami yang semula hanya merupakan limbah dari industri perkayuan (mebel) dan hasil samping pertanian, dengan adanya proses pembuatan briket bioarang dapat meningkatkan nilai pakai dari bahan tersebut sehingga dapat dimanfaatkan sebagai sumber energi alternatif. Tekanan berpengaruh terhadap mutu briket yang dihasilkan, semakin tinggi tekanan mengakibatkan partikel terdesak untuk mengisi rongga yang kosong, sehingga berkurangnya porositas pada biobriket, karena semakin kecil nilai porositasnya semakin baik briket dalam penggunaanya. Penambahan arang serbuk gergaji pada briket jerami juga berpengaruh terhadap termperatur pembakaran briket, semakin banyak komposisi penambahan arang serbuk gergaji, semakin besar temperatur pembakarannya. Rasio pemcampuran yang menghasilkan mutu briket terbaik dengan porositas terkecil dan temperature pembakaran terbesar adalah komposisi jerami padi $30 \%$ dan serbuk gergaji $70 \%$ dengan tekanan pengempaan $3000 \mathrm{~kg}$. Penelitian lebih lanjut dibutuhkan untuk mengkaji teknis dan ekonomis briket jerami padi dengan penambahan serbuk gergaji sebagai bahan bakar alternatif.

\section{UCAPAN TERIMAKASIH}

Terimakasih kepada Kepala Laboratorium Fisika UNNES Semarang yang telah memberikan sarana dan prasarana untuk mendukung kegiatan penelitian ini serta kepada semua pihak yang telah membantu dalam kegiatan penelitian.

\section{REFERENSI}

[1] Wibowo, A. S. (2009). Kajian Pengaruh Komposisi dan Perekat pada Pembuatan Briket Sekam Padi terhadap Kalor yang Dihasilkan. Jurusan Fisika Fakultas Matematika dan Ilmu Pengetahuan Alam, Universitas Diponegoro, Semarang.

[2] Mulyadi, F. A., Dewi, I. A., \& Deoranto, P. (2013). Pemanfaatan Kulit Buah Nipah untuk Pembuatan Briket Bioarang sebagai Sumbr Energi Alternatif. Jurnal Teknologi Pertanian.

[3] Hendra, D. (2011). Pemanfaatan Enceng Gondok (Eichornia crassipes) untuk Bahan Baku Briket sebagai Bahan Bakar Alternatif. Jurnal Penelitian Hasil Hutan.

[4] Asy'ari, M. I., \& Sudibandriyo, M. (2014). Pemanfaatan Jerami Padi untuk Produksi Karbon Aktif dengan Aktivasi Kimia Menggunakan Kalium Karbonat. FT UI. 
[5] Riyanto, S. (2009). Uji Kualitas Fisik dan Uji Kinetika Pembakaran Briket Jerami Padi dengan dan Tanpa Pengikat. Tekni Mesin Fakultas Teknik Universitas Sebelas Maret.

[6] Wijayanti, D. S. (2009). Karakteristik Briket Arang dari Serbuk Gergaji dengan Penambahan Arang Cangkang Kelapa Sawit. Departemen Kehutanan Fakultas Pertanian Universitas Sumatera Utara.

[7] Sudiro, \& Suroto, S. (n.d.). Pengaruh Komposisi dan Ukuran Serbuk Briket yang Terbuat dari Batu Bara dan Jerami terhadap Karakteristik Pembakaran . Jurnal Saintech Politeknik Indonusa Surakarta.

[8] Ndraha, N. (2010). Uji Komposisi Bahan Pembuat Briket Bioarang Tempurung Kelapa dan Serbuk Kayu terhadap Mutu yang Dihasilkan. Fakultas Pertanian Universitas Sumatera Utara.

[9] Setiawan , A., Andrio, O., \& Coniwanti, P. (2012). Pengaruh Kompisisi Pembuatan Biobriket dari Campuran Kulit Kacang dan Serbuk Gergaji terhadap Nilai Pembakaran. Jurnal Teknik Kimia.

[10] Sriatun, \& Yulianto, A. (2011). Uji Porositas Briket Hasil Pengolahan Limbah Glukossa. Lontar Physics Forum (p. 215). Semarang: Ikip PGRI Semarang Prress.

[11] Purwanto, D. (2015). Pengaruh Ukuran Partikel Tempurung Sawit dan Tekanan Kempa Terhadap Kualitas Biobriket. Jurnal Penelitian Hasil Hutan.

[12] Subroto. (2007). Karakteristik Pembakaran Briket Campuran Arang Kayu dan Jerami. Media Mesin. 